\title{
Does Dictogloss Improve Non-English Major Students' Motivation and Grammatical Competence?
}

\author{
Hang Nguyen \\ Thuyloi University, Hanoi, Vietnam
}

This 12-week research examined the effects of dictogloss on the students' grammatical competence and motivation. Data were collected through tests, questionnaires, and observation involving twenty eight students in a maths classat a higher education institution in Vietnam. The initial data indicated that students had low grammatical competence and motivation in learning grammar. By analyzing the textbook, the researcher found out it was structured in a way where dictogloss could be applicable and then an action plan was made to better the situation. The findings demonstrated the positive impacts of using dictogloss in the class where English was taught as an EFL (English as a foreign language). Learners could not only make improvements in their grammatical competence but also express greater interest in the English class. The dicussion supports the use of dictogloss as an alternative method for grammar teaching and provides some implications for better dictogloss practice in EFL context.

Keywords: Dictogloss, grammatical competence, grammar, motivation

Teaching grammar in an interesting and communicative way has been always given some concern by the practitioners of Teaching English as a Foreign Language (TEFL). Due to theoretical and empirical developments in the fields, many attempts have been given to this task and a number of approaches have been proposed, including grammar-based approaches, communication-based approaches, and communicative focus on form (Nassaji and Fotos, 2011). Recent research points out that form-focused instruction benefits learners of English in modifying their interlanguage grammar, which leads to the improvement of linguistic accuracy (Doughty \& Williams, 1998; Norris \& Ortega, 2000; Ellis, 2002).

One of such focus-on-form techniques is dictogloss which was first introduced by (Wajnryb, 1990) as an alternative technique of teaching grammar (Vasiljevic, 2010). It is claimed to encourage learners to concentrate on the form of language on basis of communication (Ellis, 2003). Dictogloss is a task-based procedure to help language learners better understand how grammar works on a text basis (Wajnryb, 1990). It requires a text with recurrences of target grammar structures.

Language Education in Asia, 2017, 8(1), 84-108. http://dx.doi.org/10.5746/LEiA/17/V8/11/A06/Nguyen 
At Non-English Major Division, at Hanoi College of Education $(\mathrm{HCE})^{1}$, where English is one of the mandatory subjects and all students irrespective of their majors are required to follow three compulsory English courses. After the course, learners are expected to be at the preintermediate level. Unfortunately, the teaching practice in the classroom did not reflect on the appropriate approaches in the English language Teaching (ELT) theory. After long courses, many non-English major students remained unconfident to naturally produce the grammatically correct sentences as well as expressed low interest in grammar lessons. After analyzing the textbook and the situation, the researcher found out that dictogloss might be utilizable in her context.

The study aimed to investigate the impacts of using dictogloss in teaching grammar intergratedly. This paper starts by looking at literature review on grammar instruction, dictogloss and its relations with grammar teaching, and motivation, which is followed by methodology section. The study then presents the findings and discusses them in light of relevant literature. Lastly, the conclusion emphasizes the findings and gives suggestions for further study.

\section{Grammatical Competence}

\section{Literature Review}

Historically, approaches to grammar teaching have undergone many changes due to a number of theoretical and empirical developments in the fields (Nassaji and Fotos, 2011). Apart from traditional approaches, currently, the rise of Communicative focus on form, which refers to grammar instruction that takes place in communicative contexts, has been widely advocated by a great number of scholars (Long, 1991; Skehan, 1996; Savignon, 2001; Nassaji and Fotos, 2011). Many authors have developed frameworks for grammar teaching that emphasize the incorporation of a focus on grammar into meaningful communication to help learners improve learners' grammatical competence.

Grammatical competence is developed by Canale and Swain (1980) on the basis of Chomsky's introduction of the term "competence" which "refers to knowledge of grammar and of other aspects of language" (Chomsky, 1965) and notions of communicative competence (Hymes, 1972; Campbell and Wales, 1970). According to Canale and Swain (1980), grammatical competence is associated with the mastery of the linguistic codes which enables the speakers to use necessary knowledge and skills to understand and express the literal meaning of utterances. It is aimed at acquiring knowledge of, and ability to use, forms of expression that are grammatically correct and accurate (Díaz-Rico \& Weed, 2010; Gao, 2001). Orwig (1999) also defined grammatical competence as the ability to recognize and produce grammatical structures of a language and to use them effectively in communication. Larsen-Freeman (2001) claimed that teachers needed pay attention to the three dimensions of grammar including form (structure), meaning (semantics) and use (pragmatics). Teaching grammar rules and/or having student memorize verb conjugations would not help students acquire grammatical competence. Hence, a number of researchers insisted on the inclusion of focus on form in grammar pedagogy which refers to the learners' attention on particular linguistic forms in the

\footnotetext{
${ }^{1}$ Hanoi College of Education: has changed its name to Hanoi Metropolitan University since 2014
} 
context of meaningful communication. It is "an instructional option that calls for an integration of grammar and communication in second language teaching" (Nassaji and Fotos, 2011, p.1).

\section{Motivation}

According to Martin (2003), motivation is learners' energy and drives to study, a stimulant for achieving a specific target (Johnstone, 1999). It is the efforts which learners make for learning a language because of "their need or desire to learn it" (Ellis, 1994, p.715). It is closely associated with "arousal, attention, anxiety, and feedback of reinforcement" (Franken, 1994).

Ryan \& Deci (2000) categorised motivation into two types. Intrinsic motivation refers to the inner eagerness and interest to do and participate in a particular activity as they find these activities enjoyable. On the other hand, extrinsic motivation comes from outside of the performers. Extrinsically motivated students study for the sake of outside influences such as getting teacher and peer praise, acquiring a good grade or some other type of reinforcement that a teacher or peer might offer. According to Fisher (1990) there are three major sources of motivation in learning including: (1) the learner's natural interest: intrinsic satisfaction, (2) the teacher institution employment: extrinsic reward, and (3) success in the task: combining satisfaction and reward.

Johansson (2010) showed that learners easily lose their motivation in traditional grammar classes. This approach was considered as a deductive and linear presentation of these rules and learners were exposed to too much mother tongue and rules, there was little chance for them to practice the target language. Hence, this kind of instruction failed to satisfy the communicative needs of language learners (Nassaji and Fotos, 2011).

\section{Dictogloss as an Educational Intervention}

Dictation has made its long history in language teaching and obtained a number of pedagogical claims for its value from methodologists. Due to some criticisms, several variations of dictation were made to make dictation more interesting and learner-centered. One of them is Dictogloss, also called Grammar dictation, developed by Wajnryb (1990). It is "a task-based procedure designed to help language-learning students towards a better understanding of how grammar works on a text basis." (Wajnryb, 1990, p.6). Its procedure involves four steps.

Step 1 - Preparation - This step informs students of the aim of the task. It equips learners with subject matter and vocabulary and makes them more "receptive" to listening in the next stage.

Step 2 - Dictation - The text should be dictated at normal speed twice or three times. In the first time of listening, students just listen to the general idea of the text. The second time, they take notes of the key words from which sentences and text will be constructed.

Step 3 - Reconstruction - Students are involved in reconstructing the text as accurately as possible by working in small groups. 
Step 4 - Correction - With the teacher's help, learners are required to analyze the similarities and differences with the original version, and then correct their texts.

\section{Variations of Dictogloss}

Beside the standard procedure, Jacobs and Small (2003) suggested 8 variations of dictgloss.

Dictogloss negotiation. Students discuss after each part of the text. The teachers pause the audios after one sentence or a short paragraph.

Student-controlled Dictation. Students work directly with the teacher as they use a tape recorder. They can request the teacher to stop, rewind, and fast-forward.

Student - student Dictation. Instead of the teacher reading the text, it is students that take turns to dictate the text. It can also be done by students bringing in the own texts.

Dictogloss summaries. Students concentrate on the main ideas of the original text and work with a partner to summarize the key points of the text.

Scrambled sentence dictogloss. It is employed to draw students' attention on how texts fit together. The teacher jumbles the sentences of the text before delivering it to students and learners first have to produce what they heard and then put it into a logical order.

Elaboration dictogloss. Students not only recreate a text but also to improve it. After taking notes, students reconstruct the text and then add elaborations.

Dictogloss opinion. Students give their personal opinions on the writers' ideas after reconstructing the text.

Picture dictation. Dictation can be done by completing a graphic organizer or drawing. After doing a drawing, students compare their drawings with their partners and with the original.

Teaching grammar in a motivating way has been always given some concerns by language educators and teachers. Dictogloss was taken notice of in the focus-on-form literature review, a development in the theory of grammar instruction, as one of the teaching strategies that helps to address the problems of traditional approaches since its introduction (Wajnryb, 1990). The purpose of dictogloss is to improve students' knowledge of text structure and grammar within an authentic context (VanPatten et al., 2009), and to effectively address grammatical errors in writing that may be the result of erroneous aural perception of English." (Frodesen, 1991, p. 268). Dictogloss is not only the useful for literary English, but also encourages the students to appreciate the way of choosing words and phrasing, which familiarizes them with authentic English (Ghaderpanahi, 2012). Wajnryb (1990) claims dictogloss helps to encourage learners' motivation because its procedure allows them to raise their voice and teachers teach the students in response to their need. "Dictogloss procedure can capitalize on learners' willingness to learn and allow the teacher to maintain learner motivation at a high and effective level" (p.15). This was also supported by AISibai (2017), Harwood (2008), and Gopal 
(2012); Kanazawa (2017). Hence, dictogloss embraces the potential to address the traditional concerns of grammar instruction (AISibai, 2017), to serve as a form-focused technique (Jacobs \& Small, 2003) accommodating learners' interests (Stewart et al., 2014).

In fact, the efficacy of dictogloss in promoting grammar knowledge has been empirically examined in many contexts; however, to the best of the researcher's knowledge, there have been very few studies that had assessed the value of this procedure in grammar teaching in the Southeast Asia. Furthermore, all research did only explore the impacts of standard dictogloss procedure while there were eight variations of dictogloss (Jacobs and Small, 2003). It inspired the researcher's attempt to address the gaps.

\section{Research Aims}

This study aimed to empirically measure the influences of using dictogloss on students' grammatical competence and their motivation in grammar lessons. To fulfill this aim, the study seeks to answer the following research questions:

1. How did dictogloss influence the students' grammatical competence?

2. How did it motivate students in the lessons?

\section{Participants}

\section{Methodology}

The research was carried out in 12 weeks during the second semester in the academic year 2012-2013. Partipants in this study were 28 second-year students majoring in Maths at HCE. They were in a mixed-level class as they did not take any official placement tests up on the enrollment. Typically, those participants had been studying English for about ten years as a subject prior to entering university and had already experienced the two first parts of the course (English 1 and 2) in the previous semesters. Therefore, these participants might acquire some basic listening and speaking skills as well as certain knowledge of grammatical points. However, all of them had not been equipped with note-taking skills before, so it was necessary for the researcher to gradually familiarize them with note-taking so that they could participate in dictogloss procedure. After the target course, their English was expected to be at the preintermediate level.

\section{Pedagogical Design}

New English file is a textbook for a grammar-based comprehensive course with all skills and components. In other words, target grammatical items of each lesson appear repeatedly in other skill tasks, namely reading and listening. This is really suitable for using dictogloss as a technique in the class.

For English 3, students were equipped with some popular topics from File 7 to file 9. Each week, there are 3 forty-five-minute periods. Teachers are encouraged to use as much English in the class as possible. After this course, students are expected to (1) improve their grammatical competence with a deeper understanding of its usages in real context, (2) develop their language skills such as listening, note-taking, speaking, writing, (3) develop their interaction 
with others by kinds of grouping (group work, pair work), and (4) increase greater motivation in the grammar-based class.

\section{Data Collection Instruments}

Data collection in this study included (a) the delivery of a pre- and post-test to all participants and analysis of the responses; (b) the delivery of a pre- and post- questionnaire and analysis of responses; and (c) the analysis of observation data.

A pre- and post-test. The pre-test (see Appendix A) and the post-test (see Appendix B) were designed to test learners' achievement before and after the intervention in order to find out the results of the whole treatment. To ensure the reliability and validity, the pre-test and the posttest are the same in structure, test items, target grammar, and level of difficulty. The two tests covered all grammatical components in the target files. They comprised of four parts which required students to recognize grammar items and utilize them to produce their own written works.

A pre- and post- questionnaire. Pre-questionnaire (see Appendix C) and post-questionnaire (see Appendix D) were a combination of multiple choice questions, open questions and likert scale questions collecting participants' background and their responses towards traditional grammar class and dictogloss procedure. To avoid the misunderstanding and gather the most reliable responses, both questionnaires were originally written in Vietnamese.

Observation. It was implemented during the whole period noting teachers' familiarity with dictogloss and the problems they encountered when implementing it. This helped the researcher know whether the activities were properly carried out to make some prompt adjustments.

\section{Procedure}

The action research was conducted during 12 weeks in the second semester of the academic year 2012-2013, following 7 primary steps proposed by Mc Bride \& Schostak model (1989). 


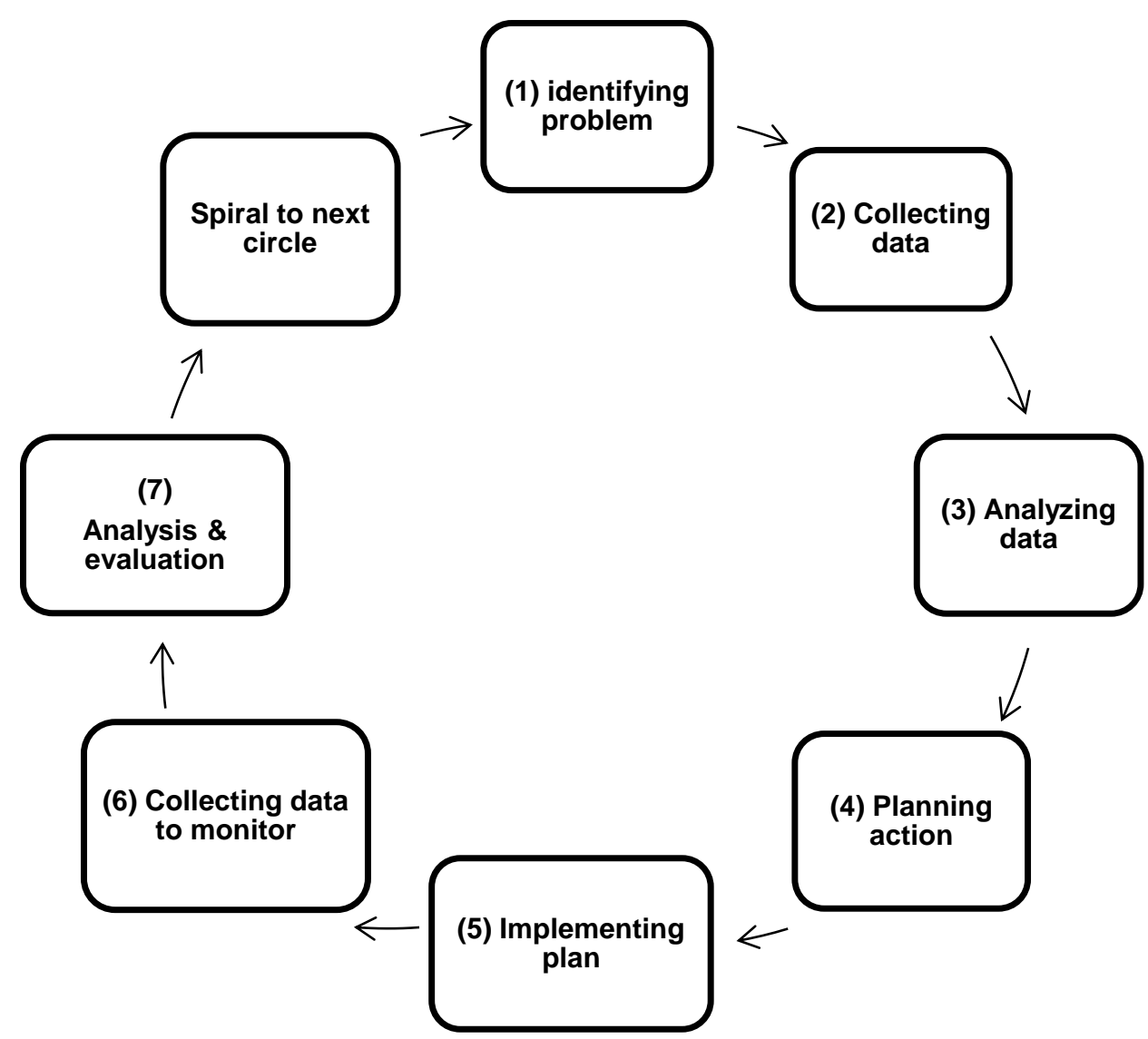

Figure 1.7 - step action research cycle

After administering a pre-test and pre-questionnaire at the first research week, data were statistically interpreted and a hypothesis "Applying dictogloss could raise the students' interest and grammatical competence." was formed. Then, a training session (week 2) was held to familiarize students with note-taking and dictogloss. The action plan was done between week 3 and week 10; the action might be slightly adjusted based on data from observation. Post data (from a post-test and a post-questionnaire) were collected and analyzed in the two following weeks.

\section{Findings}

This section presents the detailed findings for the two research questions based on the analysis of three data collection tools including tests, questionnaires, and observation.

\section{Students' Grammatical Competence}

The changes in students' grammatical competence after the intervention could be first revealed by analyzing and comparing the findings of the two tests. The overall results showed that the use of dictogloss in grammar lessons could improve their grammatical performance. 
Table 1

Student's results of pre-test and post-test

\begin{tabular}{clccl}
\hline \multicolumn{1}{c}{ Test performance } & Pre/Post & Number of Students & Percentage & Pre/Post Difference \\
\hline \multirow{2}{*}{ Weak (mark under 5) } & Pre & 6 & $21.4 \%$ & \\
& Post & 20 & $7.1 \%$ & $-14.3 \%$ \\
\hline \multirow{2}{*}{ Average (mark 5 - 6.9) } & Pre & 13 & $46.4 \%$ & \multirow{2}{*}{$-7.1 \%$} \\
\hline \multirow{2}{*}{ Fair (mark 7 - 7.9) } & Post & 11 & $39.3 \%$ & $10.7 \%$ \\
& Pre & 3 & $25 \%$ & $14.3 \%$ \\
\hline \multirow{2}{*}{ Good (Mark 8 - 8.9) } & Post & 7 & $14.3 \%$ & \\
& Pre & 4 & $10.7 \%$ & $3.6 \%$ \\
\hline \multirow{2}{*}{ Excellent (mark 9-10) } & Post & 3 & $7.2 \%$ & \\
& Pre & 2 & $17.9 \%$ & $10.7 \%$ \\
\hline
\end{tabular}

Note. Pre $=$ Pre-test, Post $=$ Post-test

It was clearly seen that from the pre-test data, nearly half of the students received a mark in the range from 5 to 6.9 while the total number of fair, good, and excellent marks accounted for slightly over $32 \%$. This result showed an unsatisfactory level of grammatical competence. In contrast, from the Pre/Post Difference data, a fall in the percentage of weak and average marks, and an increase in that of fair, good, and excellent marks indicated that there was an improvement in students' grammar test performance (see Table 1).

Looking into students' performance on separate tasks in both tests (see table 2a and 2b), it is obviously seen that multiple choice exercises were constantly done the best by the participants with the highest percentage of score group A (80\%-100\% correct ) in pre-test and post-test $(89.3 \%$ and $92.9 \%$, correspondingly) while sentence transformation tasks took up the highest portions of score group C $(<50 \%$ correct $)$ in both tests.

Table 2a

Comparison the students' performance in pre-test tasks

\begin{tabular}{llll}
\multicolumn{1}{c}{ Tasks / score groups } & \multicolumn{1}{c}{$\mathbf{A}$} & $\mathbf{B}$ & C \\
Multiple choice & $\mathbf{8 0 \% - 1 0 0 \% \text { correct }}$ & $\mathbf{5 0 \% - 7 9 \% \text { correct }}$ & $\mathbf{5 0 \% \text { correct }}$ \\
\hline Mistake correction & $89,3 \%$ & $10.7 \%$ & $0 \%$ \\
\hline Building full sentences & $42,8 \%$ & $53,6 \%$ & $3,6 \%$ \\
\hline Sentence transformation & $21.4 \%$ & $17.9 \%$ & $60.7 \%$ \\
\hline Paragraph writing & $14.3 \%$ & $17.9 \%$ & $67.8 \%$ \\
\hline
\end{tabular}

Table 2b

Comparison the students' performance in post-test tasks

\begin{tabular}{|c|c|c|c|}
\hline Tasks / score groups & $\begin{array}{c}A \\
80 \%-100 \% \text { correct }\end{array}$ & $\begin{array}{c}\text { B } \\
50 \%-79 \% \text { correct }\end{array}$ & $\begin{array}{c}\text { C } \\
<50 \% \text { correct }\end{array}$ \\
\hline Multiple choice & $92.9 \%$ & $7.1 \%$ & $0 \%$ \\
\hline Mistake correction & $64.3 \%$ & $35.7 \%$ & $0 \%$ \\
\hline Building full sentences & $35.7 \%$ & $35.7 \%$ & $28.6 \%$ \\
\hline Sentence transformation & $35.7 \%$ & $25 \%$ & $39.3 \%$ \\
\hline Paragraph writing & $21.4 \%$ & $64.3 \%$ & $14.3 \%$ \\
\hline
\end{tabular}

Note: Score groups, including A, B, and C, are named by the researcher to facilitate the analysis. They are the percentage of correct answers in each task. 
Upon closer inspection the data on students' performance in different tasks in pre-test and posttest revealed there was an overall positive change. The percentage of score group A $(80 \%-$ $100 \%$ correct) in the post-test was on the rise in all types of tasks except the task 5 and that of score group C (50\% correct) saw a downward trend in comparison with the pre-test.

When analyzing Question 6 in the prequestionnaire, the researcher understood the students' exact troubles when doing the grammar tests. Compared with only $4.5 \%$ of the responses "I have no problems with the grammar test", the biggest problem recorded was students' failure in applying long units such as building sentences even though they knew the rules (accounting for $54.6 \%$ ), followed by their inability to recognize and remember the grammar points in the quiz (up to $40.9 \%$ ).

However, an inspection into tests results revealed that there is an improvement in the participants' knowledge of grammar when doing grammar exercise. Moreover, for the tasks (such as task 4 and 5) which required deep understanding and master of grammatical rules to be able to use them effectively in communicating a message, students demonstrated increased performance after the intervention. This indicated that to some extents students did improve their grammatical competence.

To be more reliable, the author analyzed the post-questionnaire (see Appendix D) data, which revealed that a large percentage of students $(82.5 \%)$ could recognize their improvement in grammatical competence and about $17.5 \%$ were not satisfied with what they gained from the course.

Table 3

Students' evaluation on their grammatical competence improvement after the intervention

\begin{tabular}{ll}
\hline \multicolumn{1}{c}{ Students' evaluation } & Percentage \\
\hline I see no improvement & $5 \%$ \\
\hline I have experienced a little improvement & $12.5 \%$ \\
\hline I feel excited as I have made progress in doing grammar exercises & $37.5 \%$ \\
\hline I can apply the target rules into building sentences with few mistakes. & $25 \%$ \\
\hline I can apply the target rules in communicating some common messages & $20 \%$ \\
\hline
\end{tabular}

Data from observation showed that after each dictogloss procedure, students were required to take part in some practice exercises and then apply the rules in communication. Overall, the completion of the tasks was good except several students with very poor performance. They still misunderstood between a few and a little and made mistakes because they could not distinguish some uncountable and countable nouns; or between adjectives (ing) and (ed); This could also strengthened by data from post-questionnaire.

Now I am less confused with some grammatical points. For example, "a little" and "a few". Sometimes, I remember it right, but sometimes I use it wrong as I am confused between the two. (Reflection 1 for question 1) 
I found that I did make some progress. However, in several cases, I couldn't identify which was the characteristic and which was just the emotion. Hence, I was unable to give the right answers. (Reflection 2 for question 1)

\section{Students' Motivation in the Classroom}

A majority of students did not respond positively to the traditional method, which was shown in the pre-questionnaire's results. A large number of participants agreed that they felt discouraged due to the uninteresting methods and their inability in applying the rules into doing exercises and communication.

However, data from observations demonstrate that dictogloss contributed to the exciting atmosphere in the classroom. Through observation, the researcher found the class atmosphere quite exciting. In the class, most students actively took part in activities; the grouping of mixed-level students had some advantages. Because the whole lesson was often held to be a competition, all the teams wanted to win the game to receive a certain kind of rewards or merely satisfy themselves. Therefore, the group members tried to be engaged in the procedure. When the tasks (week 3- "used to") were delivered, a group leader encouraged her members "Come on, guys!", or any groups who were the fastest or were the only group to give the correct answers, they shouted and clapped their hands.

Regarding the topics, "Rebel at school" and "Useful inventions by women" turned out to be of their interest. The former made the learners amused as it reminded them of their time at school; and the latter awoke their curiosity. The topic "Weekends" was reported to be the most unexciting and uninformative.

Overally this result matched with data from the post-questionnaire (see table 4). The participants, after the intervention, expressed clear interest to the new technique. A majority did not feel sleepy during the lesson, and they were involved in the different activities of dictogloss procedure. Group work during digtogloss procedure seemed to have great impacts on the students as up to $53.6 \%$ agreed that group work made them more confident and they liked to discuss what they learnt as they could remember the rules longer (accounting for $60.7 \%)$. 


\section{Table 4}

Students' attitudes to dictogloss

\begin{tabular}{|c|c|c|c|}
\hline \multirow{2}{*}{ Attitudes } & \multicolumn{3}{|c|}{ Scale } \\
\hline & 1 & 2 & 3 \\
\hline 1. Sleepy, as I do not understand anything. & $60.7 \%$ & $32.1 \%$ & $7.2 \%$ \\
\hline 2. Sleepy, as some dictation texts are really boring. & $28.6 \%$ & $57.1 \%$ & $14.3 \%$ \\
\hline $\begin{array}{l}\text { 3. Even though I have to struggle in the first steps of dictogloss, its last steps } \\
\text { still help me to understand the target grammar. }\end{array}$ & $32.1 \%$ & $42.9 \%$ & $25 \%$ \\
\hline 4. Group work helps me feel more confident. & $17.9 \%$ & $28.5 \%$ & $53.6 \%$ \\
\hline $\begin{array}{l}\text { 5. Great as I have more chance to discuss about what we've learnt. This will } \\
\text { enhance our memory. }\end{array}$ & $14.3 \%$ & $25 \%$ & $60.7 \%$ \\
\hline $\begin{array}{l}\text { 6. It is great that the teacher immediately correct the mistakes in our } \\
\text { reconstructions. }\end{array}$ & $21.4 \%$ & $3.6 \%$ & $75 \%$ \\
\hline $\begin{array}{l}\text { 7. Encouraged as I could remember and apply the target grammar in real } \\
\text { situations because it is used in context. }\end{array}$ & $17.9 \%$ & $32.1 \%$ & $50 \%$ \\
\hline 8. I felt motivated because I made an obvious improvement. & $25 \%$ & $57.1 \%$ & $17.9 \%$ \\
\hline
\end{tabular}

Dictogloss was advocated because the way the teacher corrected the mistakes attracted them (75\%). Half of the learners felt encouraged as they could remember and apply the target grammar in real situations because it was used in context.

Data from post-questionnaire reported that nearly half of the responses indicated that students felt quite inspired in learning grammar and doing grammar tasks as they could understand and do the tasks, in comparison to a small percentage of opinions (about 13.2\%) which complained that learning grammar was still a huge challenge. Here are some extra reflections from participants.

To me, grammar is not a nightmare as it used to be. Formerly, I learnt the rules mechanically and did the exercises based on the signs in the sentences without really understanding its usage. It was problematic as it only worked well in multiple choice exercises. Therefore, I often failed in other exercises such as sentence tranformation. (Reflection 1 for question 5)

In dictogloss procedure, I had to reconstruct a paragraph on basis of the key words from the text. This task helped me be more confident with "Building full sentences" exercise. (Reflection 2 for question 5)

Noticeably, the use of dictogloss helped to lessen the fear of learning grammar and nearly $30 \%$ students increased their autonomy in doing extra grammar exercises at home to improve their grammatical competence. This was very promising and it could be seen as the target of language education.

The students' expectations and recommendations for the use of dictogloss were also collected. They said that teacher should pay more attention to grouping because some weaker students could not keep up with the stronger ones. Finally, many participants noted that they wanted 
their group to be marked at the end of the discussion. This would make the discussion a competitive game.

\section{Discussion}

The findings of the study demonstrate that language teachers should be aware that dictogloss is feasible and appropriate for teaching grammar through the design and implementation of meaningful tasks (Akbari, 2012). Jibir Daura (2013) recommended that teachers try to use dictogloss in the classroom so that learners could benefit from cooperative activities. The reported findings, to some extent, were in line with the results of previous studies (Kidd, 1992; Harwood, 2008; Qin, 2008; Gopal, 2012; Abbasian \&Minagar, 2012; AlSibai, 2017) advocating the applying dictogloss to direct learners' attention to grammatical form (Akbari, 2012; Khoii \& Pourhassan, 2015; Lindstromberg et al., 2016) while engaged in meaningful tasks (Basterrechea \&García Mayo, 2014) and to fuel learners' motivation in the class (Abbasian \& Mohammadi, 2013; Dista, 2017). Students made a progress in producing grammatical structures of a language and expressing the literal meaning of utterances (Canale \& Swain, 1980; Akbari, 2012). After the intervention, they were naturally involved in order to work out the grammar rules and see its real usage in the context and they were also given chances to practice the language. They could do some types of exercises that they had not performed well before such as rewriting the sentences and building sentences (Uludag \& VanPatten, 2012). Furthermore, by working in groups after listening, while the weaker students stood a better chance of learning from the others to complete the tasks which was still very challenging when they had to deal individually, the stronger could actively engage in completing the tasks and support the others.

Given the positive responses of the learners, there have been several things for further discussion. First, it is clear from the findings that dictogloss did contribute to the exciting atmostphere in the classroom. However, it is hard to claim that students have intrinsic motivation (Littlejohn, 2001) because English is only one of their minor subject at college. In response to question 2 (post-questionnaire) on the reasons for little improvement, they said "Because English is just a subject like other minor subjects we have to study at college, I cannot allocate much time for it though I might have some fun in the class." According to three major sources of motivation in learning suggested by Fisher (1990), although it may not help much in terms of their natural interest, dictogloss could improve learners' extrinsic motivation by means of their success in the task, rewards and enjoyable activities in dictogloss procedure. In fact, having language learners make a shift in their mood from low to higher level of encouragement is of a great significance. Secondly, students' motivation depended much on how interest the topics were. For example, with "Weekends" or "Morning life", reported tedious topics, teachers would find harder to raise learners' mood because they were able to predict the content. Furthermore, the content of the topic was also about trite routines at the weekends of some people, which made it difficult to warm up the class atmosphere. A remedy for this is that teachers should give room for students to make their own decisions on what topics need replacing before the course. This is what Wajnryb (1990) called "teachers teach the students in response to their need" to "maintain learner motivation at a high and effective level." (p.15) 
In a discussion on how to implement FonF tasks in the classroom, Ellis (2002) pointed out two factors that might affect its success: (1) target structure choices and (2) the extent of the instruction. Therefore, it would be more likely to be successful if teachers only delivered extensive instruction on simple noticeable structures. Furthermore, skill preparation also acts as a catalyst for dictogloss implementation in the class because Dictogloss includes a combination of multiple skills (Wajnryb, 1990). Yang Xue-qian (2007) claimed that if the students were unfamiliar with involved skills in dictogloss, they might face big troubles in understanding the text. For this study, the researcher had to set up a training session on dictogloss procedure and practice of note-taking skill before the treatment. However, students still took time to be familiar with it at the beginning of research period. Hence, it is essential that learners are well-equipped with important skills in advance.

After all, in spite of receiving positive feedbacks from the students, dictogloss is still recommended not to be used exclusively in the whole course. Hornby Uribe (2010) claimed that dictogloss is not an effective stand-alone activity for teaching target grammar. It should be only used as an alternative technique to teach grammar. When dictogloss is utilizable depends much on the features of the courses, the text-book and available materials with the recurrences of those features within the text (Ayoun \& Rafael Salaberry, 2005), and learners.

The first limitation of the study relates to the participant selection. Their English level was estimated approximately. They did not take any official tests to ensure that they have the same level. This may affect the outcomes of the study. The second issue is associated with the selected kind of tests which are in the written form. The final aim of dictogloss procedure is to enable learners to produce utterances grammatically accurately in communication. This limitation, therefore, suggests the need for further studies to emphasize the impacts of dictogloss on learners' grammatical competence by means of both written and oral tests.

\section{Conclusion}

Many language educators would probably agree that applying dictogloss in teaching grammar is promising in theory but challenging in practice. This study was conducted to explore the effects of using dictogloss on students' grammatical competence and their motivation in grammar class in Vietnamese EFL context. This study has demonstrated that students undertaking a grammar course with dictogloss as part of their learning process were able to improve their overall grammatical competence in areas such as verb conjugations, adjectives ending with -ing and -ed, unidentified nouns, and quantifiers encourage. Furthermore, they also encourage positive attitudes in the English classroom.

A significant contribution of the study to the ELT is the author's findings which help to positively advocate the use of dictogloss in the theory of language teaching. Regardless of several difficulties, using dictogloss in grammar lessons makes learning less stressful and more engaging, which helps to keep students motivated in learning grammar. 


\section{Author Note}

Hang Nguyen, Division of English, the Center for International Education, Thuy Loi University, Hanoi, Vietnam.

This study is my MA thesis that I carried out at Hanoi College of Education. I would like to extend my sincere thanks to Professor Ngo Huu Hoang, my supervisor, for guiding me through the whole process of research.

Hang Nguyen is a lecturer of English at Thuyloi University. She holds an M.A in ELT at University of Language and International Studies - VNU. Her fields of interest are ELT, materials development and teaching methodology.

Correspondence concerning this article should be addressed to Hang Nguyen, Division of English, the Center for International Education, Thuy Loi University. E-mail:

nguyenhangsphn@gmail.com 


\section{References}

Abbasian, G. R., \& Minagar, N. (2012). PI-based vs. DG-oriented Instruction in Developing Grammar Ability and Motivation of EFL Learners. Iranian EFL Journal. 8(4). 94-112.

Abbasian, G. R., \& Mohammadi, M. (2013). The Effectiveness of Dictogloss in Developing General Writing Skill of Iranian Intermediate EFL Learners. Journal of Language and Teaching Research, 4(6), 1371-1380. https://doi.org/10.4304/jltr.4.6.1371-1380

Akbari, A. (2012). Enhancing EFL Learners' Grammatical Competence through Dictogloss Method. Retrieved from http://www.academia.edu/3156061/Enhancing_EFL_Learners_Grammatical_Compete nce_through_Dictogloss_Method

Alsibai, D. M. (2017). Using Dictogloss Tasks: Attention to Form in a Collaborative Classroom Activity with Female Translation Students at King Saud University. Arab World Eng/ish Journal, 8(2). https://doi.org/10.24093/awej/vol8no2.24

Ayoun, D \& M. Rafael Salaberry. (2005). Tense and Aspect in Romance Languages: Theoretical and Applied Perspectives. Amstedam: John Benjamins https://doi.org/10.1075/sibil.29

Basterrechea, María, \& García Mayo, María del Pilar. (2014). Dictogloss and the Production of the English Third Person "-s" by CLIL and Mainstream EFL Learners: A Comparative Study. International Journal of Eng/ish Studies, 14(2), 77-98. https://doi.org/10.6018/j.177321

Campbell, R., \& Wales, R. (1970). The Study of Language Acquisition. In Lyons, J. (Ed.), New Horizons in Linguistics. Harodsworth: Pinguin Books Ltd.

Canale, M., \& Swain, M. (1980). Theoretical bases of communicative approaches to second language teaching and testing. Applied Linguistics, 1, 1-47. https://doi.org/10.1093/applin/1.1.1

Chomsky, N. (1965). Aspects of the theory of syntax. Cambridge, Mass.: MIT Press.

Díaz-Rico, L. T. \& Weed, K. Z. (2010). The crosscultural, language, and academic development handbook: A complete K-12 reference guide (4th ed.). Boston: Allyn \& Bacon.

Dista, D. M. (2017). Using Dictogloss to improve listening comprehension. English Education Journal (EEJ), 8(2), 149-163.

Doughty, C., \& Williams, J. (1998). Focus on form in classroom second language acquisition. Cambridge, UK: Cambridge University Press.

Ellis, R. (1994). The Study of Second Language Acquisition. Oxford: Oxford University Press.

Ellis, R. (2002). DOES FORM-FOCUSED INSTRUCTION AFFECT THE ACQUISITION OF IMPLICIT KNOWLEDGE?: A Review of the Research. Studies in Second Language Acquisition, 24(2), 223-236. https://doi.org/10.1017/S0272263102002073

Ellis, R. (2003). Task-based Language Learning and Teaching. Oxford: Oxford University Press.

Fisher, R. (1990). Teaching children to think. Oxford: Blackwell

Franken, R. E. (1994). Human Motivation (3rd ed.). California: Brooks/Cole.

Frodesen, J. (1991). Grammar in writing. In M. Celce-Murcia (Ed.), Teaching English as a second or foreign language ( ${ }^{\text {nd }}$ ed., pp.264-276). New York: Newbury House.

Gao, C. Z. (2001). Second Language Learning and the Teaching of Grammar. Education, 2, 326- 336 . 
Ghaderpanahi, L. (2012). Using authentic aural materials to develop listening comprehension in the EFL classroom. English Language Teaching, 5(6), 146-153.

https://doi.org/10.5539/elt.v5n6p146

Gopal, K. (2012). "The effect of Dictogloss as a language task in enhancing students" grammatical competence in SK Felda Ulu Tebrau". Retrieved from http://www.fp.utm.my/ePusatSumber/pdffail/ptkghdfwP/kanmanimp091199d12ttp.pdf

Harwood, C. (2008). A Classroom Experiment: Using dictogloss. Retrieved from http://www.academia.edu/323021/A_Classroom_Experiment_Using_dictogloss

Hornby Uribe, A. J. (2010). Using the Dictogloss in the high school foreign language classroom: Noticing and learning new grammar". Retrieved from http://repositories.lib.utexas.edu/handle/2152/ETD-UT-2010-05-1337

Hymes, D. H. (1972). On Communicative Competence. In Pride, J. B., \& Holmes, J. (Eds.). Sociolinguistics. Baltimore, USA: Penguin Education, Penguin Books Ltd.

Jacobs, G \& Small, J. (2003). Combining Dictogloss and Cooperative Learning to Promote Language Learning. The reading Matrix, 3(1), 1-15.

Jibir Daura, R. (2013). Using Dictogloss as an Interactive Method of Teaching Listening Comprehension. Advances in Language and Literary Studies, 4(2). https://doi.org/10.7575/aiac.alls.v.4n.2p.112

Johansson, A. (2010). What influences students' motivation for learning English grammar? (Unpublished thesis). Retrieved from https://www.divaportal.org/smash/get/diva2:373545/FULLTEXT01.pdf

Johnstone, R. (1999). Research on language learning and teaching: 1997-98. Language Teaching, 32(3). 137-156. https://doi.org/10.1017/S0261444800013987

Kanazawa, N. (2017). A Study of the Effectiveness of Dictogloss on English Grammar and Motivation for Japanese Junior College Students in English Communication Class. Retrieved from https://komajo.repo.nii.ac.jp/?action=repository_uri\&item_id=1242\&file_id=22\&file_n $\mathrm{O}=1$

Khoii, R., \& Pourhassan, E. (2015). Effects of Different Types of Dictation Practice on Immediate and Delayed Performance Tests of Present Tense "To Be" Verbs and Indefinite Articles. Retrieved from www.academia.edu/4195113

Kidd, R. (1992). Teaching ESL Grammar through Dictation. TESL Canada Journal. 10(1). 4961. https://doi.org/10.18806/tesl.v10i1.611

Larsen-Freeman, D. (2001). Teaching grammar. In M. Celce-Murcia (Ed.), Teaching English as a second or foreign language. $\left(3^{\text {rd }}\right.$ ed., pp. 251-266). USA: Heinle \& Heinle.

Lindstromberg, S., Eyckmans, J., \& Connabeer, R. (2016). A modified dictogloss for helping learners remember L2 academic English formulaic sequences for use in later writing. ENGLISH FOR SPECIFIC PURPOSES, 41, 12-21.

https://doi.org/10.1016/j.esp.2015.08.002

Littlejohn, A. (2001). Motivation. Where does it come from? Where does it go? Eng/ish Teaching Professional, 19, 5-8.

Long, M. (1991). Focus on form: A design feature in language teaching methodology. In K. de Bot, R. Ginsberg, and C. Kramsch (eds.), Foreign language research in cross-cultural perspective. Amsterdam: John Benjamins. https://doi.org/10.1075/sibil.2.07lon 
Mc Bride, R \& Schostak, J. (1989). Action research. Retrieved from http://www.enquirylearning.net/ELU/Issues/Research/Res1Ch4.html

Martin, A.J. (2003). How to motivate your child for school and beyond. Sydney: Bantam.

Nassaji, H. \& Fotos, S. (2011). Teaching grammar in Second Language classrooms: Integrating Form-Focused Instruction in Communicative Context. NY: Routledge.

Norris, J.M. \& Ortega, L. (2000). Effectiveness of L2 instruction: A research synthesis and quantitative meta-analysis. Language Learning, 50(3), 417-528. https://doi.org/10.1111/0023-8333.00136

Orwig, Carol J. (1999). Guidelines for a Language and Culture Learning Program. Retrieved from http://www-

01.sil.org/lingualinks/languagelearning/OtherResources/GudlnsFrALnggAndCltrLrnngP rgrm/contents.htm

Qin, J. (2008). The Effect of Processing Instruction and Dictogloss Tasks on Acquisition of the English Passive Voice. Language Teaching Research. 12(1), 61-82. https://doi.org/10.1177/1362168807084494

Ryan, R. M., \& Deci, E. L. (2000). "Intrinsic and Extrinsic Motivations: Classic definitions and new directions". Contemporary Educational Psychology, 25, 54-67. https://doi.org/10.1006/ceps.1999.1020

Savignon, S. (2001). Communicative language teaching for the twenty-fi rst century. In M. Celce-Murcia (Ed.), Teaching English as a second or foreign language (3rd ed., pp. 1328). MA: Heinle \& Heinle.

Skehan, P. (1996). Second language acquisition research and task-based instruction. In J. Willis \& D. Willis (Eds.), Challenge and change in language teaching (pp.17-30). Oxford, UK: Heinemann.

Stewart, Benjamin Lee, Rodríguez Silva, Luis Humberto, \& Torres González, Juan Antonio. (2014). Integrating Language Skills through a Dictogloss Procedure. English Teaching Forum, 52(2), 12-19.

Uludag, O. \& VanPatten, B. (2012). The comparative effects of processing instruction and dictogloss on the acquisition of the English passive by speakers of Turkish. International Review of Applied Linguistics in Language Teaching, 50(3), 189212. https://doi.org/10.1515/iral-2012-0008

Vasiljevic, Z. (2010). Dictogloss as an Interactive Method of Teaching Listening Comprehension to L2 Learners. English Language Teaching. 3(1). https://doi.org/10.5539/elt.v3n1p41

VanPatten, B., Inclezan, D., Salazar, H. and Farley, A. P. (2009), Processing Instruction and Dictogloss: A Study on Object Pronouns and Word Order in Spanish. Foreign Language Annals, 42: 557-575. https://doi.org/10.1111/j.1944-9720.2009.01033.x

Wajnryb, R (1990). Grammar dictation. Oxford: Oxford University Press. Yang Xue-qian. (2007). Listeners' Listening Comprehension. Us-China Foreign Language. 5(3). 22-31. 


\section{Appendix A}

\section{Pre-test}

\section{Use of English (20p)}

1. I'm going to this week.
a. look after my neighbour's cat
b. look my neighbour's cat after

c. look at my neighbour's cat

d. $A \& B$

2. He can't reach the top shelf because he is not very tall.

a. He is tall enough to reach the top shelf.

b. He is too tall to reach the top shelf.

c. He isn't tall enough to reach the top shelf.

d. He isn't tall, so he can reach the top shelf.

3. She really long hair but she's had it all cut off.
a. is used to have
b. used to have
c. is used to having
d. didn't use to have

4. - I get on with my boss very well. -
a. So I do
b. neither do I
c. So am I
d. So do I

5. Walking around the shopping center was quite I need a rest!
a. tire
b. tiring
c. tired
d. tires

6. Before I to class this morning, I my homework.
a. come / did
b. came/had done
c. come/ had done
d. came/ have come

7. Can you ? I want to watch the film.
a. turn the TV on
b. turn the TV in
c. turn off the TV
d. turn the TV off

8. I'm bored. I don't have to do.
a. anything
b. nothing
c. everything
d. anyone

9. The electric light bulb by Thomas Edison in 1879 .
a. was invented
b. invented
c. is invented
d. invents

10. I usually have milk in my coffee. I don't want to gain weight.
a. too many
b. a few
c. little
d. enough

\section{Mistake correction (20p)}

11. This coffee isn't enough hot for me to drink in this cold weather.
A
B
C
$\mathrm{D}$

12. He used wear a uniform when she was at school.
A B
C
D 
13. Your father's asleep. Don't wake up him! He will be very frustrated
A B
C
$\mathrm{D}$

14. My daughter was particularly impressing by the dancing.
A
B C
D

15. Even though we are not twins, I look exactly the same with my sister.
A
B
C
D

\section{Make full sentences with the given words (20p)}

16. It / is not / safe enough / walk here at night.

17. He / born / in Virginia.

18. This / is / first time / I / meet / him.

19. Every morning / I / turn / my computer / and check my e-mail.

20. Yesterday after / Kathy and Tom / do exercise, / they have a shower.

\section{Rewrite the sentences without changing the meaning (20p)}

21. The police arrested fifteen people.

$\rightarrow$ Fifteen

22. It is tiring to study late at night.

$\rightarrow$ Studying

23. I got dressed, and then she went to work.

$\rightarrow$ After

24. He often walked to the park in the evening when he was a child, but now he doesn't $\rightarrow$ He used

25. Those shoes are too small for me to wear.

$\rightarrow$ These shoes are not

\section{Writing (20p)}

Write a short paragraph (about 50 - 60 words) to talk about what you used to do in the past. In the paragraph, you must include 10 uses of the following components (try to use different components, but you don't have to use all of them). For each component used, please underline them.

$\checkmark$ Phrasal verbs

$\checkmark$ Used to

$\checkmark$ Passive

$\checkmark$ Quantifiers (much/many/a few/ few/ a little/ little/ too...to / enough ... to)

$\checkmark$ Similarity (similar, same, either, neither, so, too, look like)

$\checkmark$ Adj (ing/ ed)

$\checkmark$ Some (body /thing / where), any (body /thing / where); no (body /thing / where)

$\checkmark$ Past perfect

The end 


\section{Appendix B}

\section{Post-test}

\section{Use of English (20p)}

1. I was late for school this morning because my alarm clock didn't
A. go off
B. go up
C. go away
D. go on

2. She doesn't know much about French. She cannot read a newspaper in French.
A. She doesn't know enough French not to read a newspaper in French.
B. She doesn't know French enough to read a newspaper in French.
C. She knows too much French to read a newspaper in French.
D. She doesn't know too much French to read a newspaper in French.

3. There a petrol station there. When was it built?
A. used to be
B. used being
C. didn't use to be
D. didn't used to be

4. - A: He didn't know that she had been married. - B:
A. So did I
B. So I did
C. Neither did I
D. Neither didn't I

5. She supposed the trip would be very
A. interests
B. interest
C. interesting
D. interested

6. The film by the time we to the cinema.
A. had already started/ got
B. already started/ had gotten
C. had already started/ had gotten
D. has already started/ got

7. I was late for school this morning because my alarm clock didn't
A. go off
B. go up
C. go away
D. go on

8. I phone twice, but answered.
A. nothing
B. anything
C. somebody
D. nobody

9. English in many parts of the world.
A. is speaking
B. speaking
C. is spoken
D. speaks

10. If you can wait, we'll be there in minutes
A. few
B. little
C. a little
D. a few

\section{Mistake correction (20p)}

Identify the underlined word or phrase A, B, C or D that must be changed and then correct them.

11. We couldn't go sailing yesterday. There wasn't wind enough for both of us.
A
B
C
D 
12. He used smoke 40 cigarettes a day but he doesn't smoke any more now.
A
B
C
$\mathrm{D}$

13. Your clothes are on the floor. Why don't you put away it? We're having guests.
A
B
C
D

14. It was an extremely frightened experience in my life.
A
B
C
D

15. Dr. Bouchard didn't expect them to be so similar with each other
A
B C
$\mathrm{D}$

III. Make full sentences with the given words (20p)

16. He / was / too / old / ride / the bumper car.

17. Television / invent / John Logie Baird / in 1925.

18. We / not have / a good meal / for / three weeks.

19. I've lost / my glass. Can / you / help me/ look / them?

20. The man / lend / me / his newspaper / after / he / read / it.

IV. Rewrite the sentences without changing the meaning (20p)

21. Nobody sent us any tickets.

We

22. He found this book boring.

He was

23. Daisy and John did some exercise. Then they had a shower.

After

24. Jim was my best friend, but we aren't friends any more.

Jim used

25. He was too poor to buy a bicycle

He was not

\section{Writing (20p)}

Write a short paragraph (about 50 - 60 words) to talk about your interesting visit in the past. In the paragraph, you must include 10 uses of the following components (try to use different components, but you don't have to use all of them). For each component used, please underline them.

$\checkmark$ Phrasal verbs

$\checkmark$ Used to

$\checkmark$ Passive

$\checkmark$ Quantifiers (much/many/a few/ few/ a little/ little/ too...to / enough ... to)

$\checkmark$ Similarity (similar, same, either, neither, so, too, look like)

$\checkmark$ Adj (ing/ ed)

$\checkmark$ Some (body /thing / where), any (body /thing / where); no (body /thing / where)

$\checkmark$ Past perfect

The end 


\section{Pre-questionnaire}

\section{Appendix C}

1. Please describe your difficulties in learning grammar? (You may choose more than one)

a. I find no difficulties.

b. I can't remember many grammatical rules.

c. I don't understand, so I feel demotivated.

d. The teaching methods are uninteresting to students.

e. I find it hard to apply grammatical rules in communication.

f. Others:

2. How often do you get low scores in the grammar tests?
a. Never
b. Rarely
c. Sometimes
d. often
e. always

$*$ Low score: $=<5 / 10$

3. What do you find difficult when doing grammar tests?
a. I find no difficulties
b. I can't identify which grammatical rules are being tested.
c. I must struggle when applying grammar in building meaningful sentences.
d. Others:

4. Please tick the teaching method which was most used in the grammar class
a. Neglecting grammar
b. Teaching grammar in isolation
c. Teaching grammar through other skills
d. Others:

5. What are your attitudes in traditional grammar lessons (teaching grammar in isolation). Please tick $\mathrm{x}$ in the response which corresponds with your opinion.
$1=$ Strongly disagree
$4=$ Agree
2 = disagree
$5=$ Strongly agree

$3=$ Neither disagree nor agree

\begin{tabular}{|l|l|l|l|l|l|l|}
\hline \multirow{2}{*}{ No. } & \multicolumn{1}{|c|}{ Attitudes } & \multicolumn{3}{c|}{ Scale } \\
\cline { 5 - 7 } & & 1 & 2 & 3 & 4 & 5 \\
\hline 1 & Bored as I do not understand anything & & & & & \\
\hline 2 & Sleepy as the teacher's methods are boring & & & & & \\
\hline 3 & $\begin{array}{l}\text { Disappointed as I cannot apply grammatical rules into } \\
\text { practice. }\end{array}$ & & & & & \\
\hline 4 & $\begin{array}{l}\text { Interested as I could understand what the teacher presents. } \\
\text { Interested as I could do the exercises after the teacher } \\
\text { gives the rules. }\end{array}$ & & & & & \\
\hline 6 & $\begin{array}{l}\text { Interested as the teacher presents the rules in an interesting } \\
\text { way. }\end{array}$ & & & & & \\
\hline 7 & $\begin{array}{l}\text { Interested as I know how to use accurate grammatical } \\
\text { rules in communication. }\end{array}$ & & & & & \\
\hline
\end{tabular}


Others:

6. What are your expectations of a grammar lesson? (You can choose more than one)

a. Teachers can give examples in popular contexts or situations, so that students could easily recognize its usage.

b. Teachers have more interesting methods.

c. Sometimes teachers should allow students to work out the rules by themselves.

d. Teachers should create more chances for students to practice the rules in communication.

e. Students should practice rules in some complex exercises such as building sentences, not limited to multiple choice exercises.

f. Others: 


\section{Appendix D}

\section{Post-questionnaire}

1. Please evaluate your progress in learning grammar after the course. (You can choose more than one)
a/ I see no improvement
b/ I experienced a little improvement
c/ I have made progress in doing grammar exercises
d/ I can apply the target rules into building sentences with few mistakes.
e/ I can apply the target rules in communicating some common messages.

f/ Others:

2. In your opinion, what are the reasons for little improvement?
a/ I am not familiar with dictogloss technique.
b/ Dictogloss is quite complex, which hinders me from understanding the lessons.
c/ Dictogloss is not engaging, so I cannot stay focused.
d/ Others:

3. What are your responses towards grammar lessons with the use of dictogloss? Please indicate whether you agree or disagree with the following statements.

$$
\begin{array}{ccc}
1=\text { Disagree } & 2=\text { Neither disagree nor agree } & 3=\text { Agree } \\
* \text { Neither disagree nor agree: Sometimes right sometimes wrong } &
\end{array}
$$

\begin{tabular}{|c|l|l|l|l|}
\hline \multirow{2}{*}{ No. } & \multicolumn{1}{|c|}{ Attitudes } & \multicolumn{2}{c|}{ Scale } \\
\cline { 3 - 5 } & & 1 & 2 & 3 \\
\hline 1. & Sleepy, as I do not understand anything. & & & \\
\hline 2. & Sleepy, as some dictation texts are really boring. & & & \\
\hline 3. & $\begin{array}{l}\text { Even though I have to struggle in the first steps of } \\
\text { dictogloss, its last steps still help me to understand the } \\
\text { target grammar. }\end{array}$ & & & \\
\hline 4. & $\begin{array}{l}\text { Group work helps me feel more confident. } \\
\text { 5. }\end{array}$ & $\begin{array}{l}\text { Great as I have more chance to discuss about what } \\
\text { we've learnt. This will enhance our memory. }\end{array}$ & & \\
\hline 6. & $\begin{array}{l}\text { It is great that the teacher immediately correct the } \\
\text { mistakes in our reconstructions. }\end{array}$ & & \\
\hline 7. & $\begin{array}{l}\text { Encouraged as I could remember and apply the target } \\
\text { grammar in real situations because it is used in context. }\end{array}$ & & & \\
\hline 8. & $\begin{array}{l}\text { I felt motivated because I made an obvious } \\
\text { improvement. }\end{array}$ & & & \\
\hline
\end{tabular}

Others: 
4. What are your recommendations for better implementation of dictogloss?

5. What are your attitudes towards learning grammar now?

a/ It is still very difficult for me.

$\mathrm{b} / \mathrm{I}$ find learning grammar less difficult.

c/ I feel quite motivated with learning grammar and doing exercises because I understand it.

d/ I often look for extra exercises to improve my grammar.

e/ Others: 